\title{
Perspectives
}

\section{A Reflective Approach to Digital Technology Implementation in Language Teaching: Expanding Pedagogical Capacity by Rethinking Substitution, Augmentation, Modification, and Redefinition}

\section{Paul A. Lyddon}

As the number of language instructors seeking to implement digital technologies in their teaching continues to grow, so does the need for direction with regard to making pedagogically sound decisions concerning digital tool use. One popular and useful guide for considering the educational potential of digital technologies has been Puentedura's (2006) Substitution-Augmentation-Modification-Redefinition (SAMR) model, with its four levels of progressive technological integration. However, the degree of technological integration truly possible or even desirable for individual teachers in their given context depends on a number of complex, interrelated, largely non-technological factors, including implementation motives, pedagogical purview, educational philosophy, theory of learning, teaching style, and situational constraints. Generally unconscious, these factors often go ignored, leaving teachers susceptible to technological decisions that can lead them to lose their prescribed pedagogical focus or unwittingly contradict their core professional beliefs. After a brief, situated overview of the SAMR model, this article introduces and illustrates a five-stage $S A M R$-embedded reflective approach to systematically eliminating irrelevant, unacceptable, and unfeasible instructional uses of technology and, thereby, revealing potential for expanding pedagogical capacity in language teaching.

À mesure que grandit le nombre de professeurs de langue qui cherchent à mettre les technologies numériques au service de leur enseignement, il devient plus important de savoir prendre des décisions pédagogiques judicieuses concernant le recours aux outils numériques. Populaire et utile avec ses quatre niveaux d'intégration progressive de la technologie, le modèle SAMR (Substitution, Augmentation, Modification, Redéfinition) de Puentedura (2006) a guidé maints utilisateurs intéressés par le potentiel éducatif des technologies numériques. Toutefois, le degré d'intégration technologique effectivement possible ou même désirable pour les professeurs individuels dans leur contexte particulier dépend de facteurs complexes, interdépendants et essentiellement non technologiques tels 
que les motifs invoqués en faveur du recours à la technologie, le ressort en matière de pédagogie, la philosophie éducative, la théorie de l'apprentissage, le style pédagogique et les contraintes situationnelles. Généralement inconscients, ces facteurs restent souvent ignorés, ce qui risque de confronter les professeurs à des décisions technologiques susceptibles de leur faire perdre la focalisation pédagogique qui leur a été prescrite ou de contredire involontairement leurs convictions professionnelles fondamentales. Après avoir brièvement replacé le modèle SAMR dans son contexte, le présent article introduit et illustre une approche réflective en cinq étapes intégrées au modèle SAMR qui est destinée à éliminer systématiquement les utilisations non pertinentes, inacceptables et irréalisables de la technologie, et ouvrant ainsi la perspective d'enrichir le potentiel pédagogique de l'enseignement des langues.

KEYWORDS: technology integration, SAMR model, educational philosophies, learning theories, instructional methods

\section{Technology and "Transformation"}

In grounding their efforts to explain teacher adoption of educational technology, Sherer et al. (2019) noted the encouragement of technology use in teaching as a major global trend. In fact, TESOL, Inc. began publishing technology standards more than a decade ago (TESOL Technology Project Standards Team, 2008). In short, it is now no longer a question of whether to implement technology in our teaching, but how. In a recent interview, former director of the Office of Educational Technology for the U.S. Department of Education Richard Culatta expressed a vision of two possible futures: one in which technology "essentially duplicates what we've traditionally done" (Kash, 2018, para. 6) and another in which "we use technology in a way that transforms learning" (para. 7).

"Transformation" has become somewhat of a buzzword in contemporary education, and the push to capitalize on the supposedly transformative potential of educational technology has prompted the development of several models for technological integration. Among the most popular of these is Puentedura's (2006) Substitution-Augmentation-Modification-Redefinition (SAMR) Model, a seemingly straightforward taxonomy of progressively higher levels of technological tool affordances. Given its relative simplicity and practical appeal, the SAMR model has unsurprisingly captured the interest and imagination of many classroom teachers seeking to modernize their instruction. It is for this reason that I have chosen to focus on SAMR. 


\section{Overview of the SAMR Model}

Originally developed in the 1990s to promote greater technological investment in the commercial sector, the SAMR model has since been applied to education, including language teaching (see, for example, Kukulska-Hulme et al., 2017). The model categorizes technology use into four progressively higher levels of affordance, namely, Substitution, Augmentation, Modification, and Redefinition (see Figure 1).

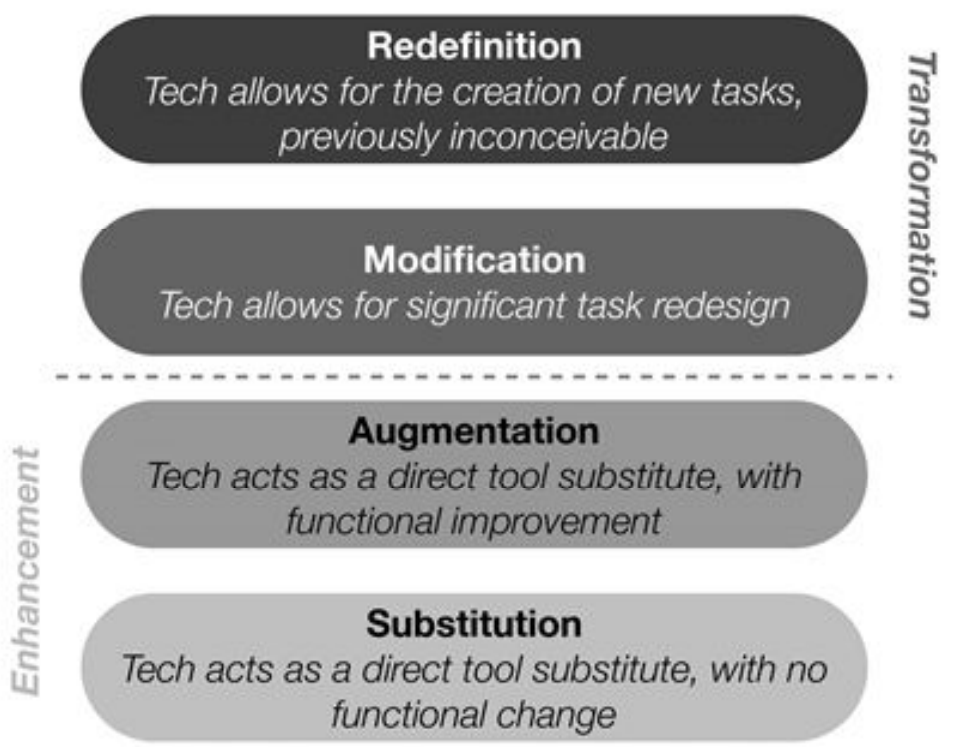

Figure 1. The SAMR Model (from Puentedura, 2015). SAMR = Substitution-Augmentation-Modification-Redefinition.

Source: Ruben R. Puentedura, As We May Teach: Educational Technology, From Theory Into Practice. (2009).

At the Enhancement levels of Substitution and Augmentation, new technologies essentially replace existing tools, albeit with some functional improvement in the case of the latter. In the context of language teaching, such as an oral communication class, Substitution might be to have students use digital versions of previously paper-based materials for class discussion activities; Augmentation might be to have them complement their oral production with digital images. The Transformation levels of Modification and Redefinition, in contrast, allow for significant task redesign and the creation of new, previously inconceivable tasks, respectively. In the same oral communication class context, Modification might be to have students record, transcribe, and analyze their oral performance; Redefinition might be to have them participate in online discussions with peers from schools in other countries (see Figure 2 for additional examples of language learning activities at all SAMR levels). 


\begin{tabular}{|c|c|c|c|c|}
\hline \multirow{2}{*}{ Level } & \multicolumn{4}{|c|}{ Communication Skill } \\
\cline { 2 - 5 } Redefinition & $\begin{array}{c}\text { Record and analyze } \\
\text { online conversation } \\
\text { with partner abroad }\end{array}$ & $\begin{array}{c}\text { Sngage in online } \\
\text { discussions with } \\
\text { peers abroad }\end{array}$ & $\begin{array}{c}\text { Compare online } \\
\text { news stories from } \\
\text { various countries }\end{array}$ & $\begin{array}{c}\text { Publish } \\
\text { compositions } \\
\text { and respond to } \\
\text { comments online }\end{array}$ \\
\hline Modification & $\begin{array}{c}\text { Transcribe and } \\
\text { analyze model } \\
\text { recorded speech }\end{array}$ & $\begin{array}{c}\text { Record, transcribe, } \\
\text { and analyze own } \\
\text { speech }\end{array}$ & $\begin{array}{c}\text { Read user } \\
\text { responses to online } \\
\text { news articles }\end{array}$ & $\begin{array}{c}\text { Create multimodal } \\
\text { compositions }\end{array}$ \\
\hline Sugmentation & $\begin{array}{c}\text { Record and re-listen } \\
\text { to class lectures }\end{array}$ & $\begin{array}{c}\text { Present multimodal } \\
\text { slide shows }\end{array}$ & $\begin{array}{c}\text { Read online texts } \\
\text { with color images }\end{array}$ & $\begin{array}{c}\text { Write and } \\
\text { compare drafts } \\
\text { with collaborative } \\
\text { software }\end{array}$ \\
\hline Substitution & $\begin{array}{c}\text { Listen to MP3s } \\
\text { instead of CDs }\end{array}$ & $\begin{array}{c}\text { Use digital versions } \\
\text { of activities instead } \\
\text { of paper }\end{array}$ & $\begin{array}{c}\text { Read traditional } \\
\text { handouts as PDFs }\end{array}$ & $\begin{array}{c}\text { Type in an app } \\
\text { rather than write on } \\
\text { paper }\end{array}$ \\
\hline
\end{tabular}

Figure 2. Example SAMR learning activities for traditional communication skills. $S A M R=$ Substitution-Augmentation-Modification-Redefinition; $M P 3=M P E G$ (Moving Picture Experts Group) Audio Layer-3; $C D=$ compact disc; $P D F=$ portable document format.

Despite its popularity, the SAMR model has several notable shortcomings, not the least of which is its unspecified use of the variously understood term "transformation." In educational philosophy and curriculum theory, for instance, "transformative education" seeks to alter learner perspectives in order to motivate radical social change (Crookes, 2016). In educational psychology, however, in both the rational, cognitive, analytical "transformative learning theory" of Mezirow (1978) and the intuitive, creative, holistic "transformative education" of Boyd and Myers (1988), the ultimate objective of shifting learner perspectives is to improve comprehension of individual lived experience. Slavich and Zimbardo's (2012) "transformative teaching" is yet another variation - in this case, an umbrella term encompassing various pedagogical approaches aimed at creating dynamic relationships between teachers, students, and a shared body of knowledge to promote personal student growth. Although not entirely incompatible, these multiple perspectives are clearly not identical. In short, whatever one's understanding of the ultimate goals of "transformation," it should at least be clear in the mind of the would-be transformer.

Hamilton et al. (2016) point out three other important shortcomings of SAMR, namely, its prescriptive taxonomic structure, its disregard for contextual differences, and its focus on learning activities rather than processes, all of which can be seen in the following example from my personal experience, when, several years back, the private university where I was teaching English summarily implemented a policy requiring all incoming students to 
purchase tablet computers. Up to that point, I had no familiarity with mobile technology nor the inclination to acquire any. Suddenly, I found myself obligated to somehow shoehorn tablet use into my daily teaching practice, which had heretofore been reasonably successful with the traditional activities I had been using. As much of my lesson time was dedicated to oral communication, the most obvious response was to make the transparently meaningless substitution of converting my paper materials to digital form. Some of my more adventurous colleagues experimented with more "progressive" activities, such as virtual exchanges with learners at other institutions, and these activities might, indeed, have been more interesting and enjoyable for many of the students, but it was unclear that they were in any way positively impacting student learning. Moreover, it appeared in these cases that technology use was now driving the curriculum rather than the other way around.

In spite of its shortcomings, SAMR does challenge us to consider potentially beneficial uses of technology we might otherwise not. As such, with its deficiencies firmly in mind, I will now propose a reflective approach to digital technology implementation in language teaching that addresses SAMR's oversights while capitalizing on its insights. This approach comprises five stages, covering six key reflection areas: implementation motives, pedagogical purview (i.e., curricular charge), educational philosophy, theory of learning, teaching style, and situational constraints. These reflection areas can each be framed in terms of one or more driving questions, the answers to which serve to progressively delineate our situationally constrained potential for technology-assisted pedagogical capacity expansion. The five stages are illustrated in Figures 3 through 7. Their corresponding reflection areas, driving questions, and possible answers are summarized in Figure 8. I will now exemplify the reflection process from start to finish with Freshman English, an English Language Learner (ELL) course I taught at the private university mentioned above.

\section{RADTILT: A Reflective Approach to Digital Technology Implementation in Language Teaching}

\section{Stage 1: Pre-reflection}

Under ideal circumstances, before we consider using any new technology, we should first imagine ourselves operating in an environment where our technologically unassisted pedagogical capacity is maximized with respect to our relevant pedagogical purview. In other words, even ignoring the potential of digital technologies, we strive to make the most of our currently available knowledge, skills, time, and other resources, though we rarely accomplish all we should like. A hypothetical representation of this prereflection stage is shown in Figure 3, which depicts the gap between our capacity and our purview as unattainable stakeholder needs. Note that the 
expanse of the relevant pedagogical purview varies with context, as does the extent to which technologically unassisted pedagogy covers it. In any case, the potential of digital technologies at this point lies latent in the background, completely unrealized, and only visible around the periphery.

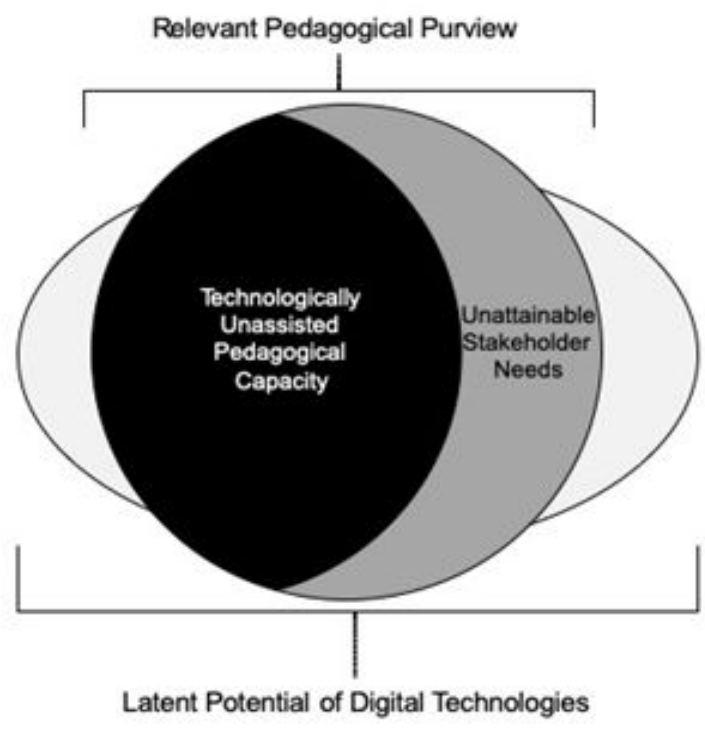

Figure 3 (above). Pre-reflection stage. Figure 4 (below). Initial reflection stage. $S A M R=$ Substitution-Augmentation-Modification-Redefinition .

\section{Stage 2: Initial Reflection}

Once we start to consider introducing digital technologies into our teaching, their potential comes to the fore, where we can imagine the four SAMR levels emerging as outwardly expanding bands, representing successively greater degrees of theoretically possible growth in pedagogical capacity (see Figure 4). Critically unexamined, however, their potential also masks the boundaries of our relevant pedagogical purview, which limits our actual options.

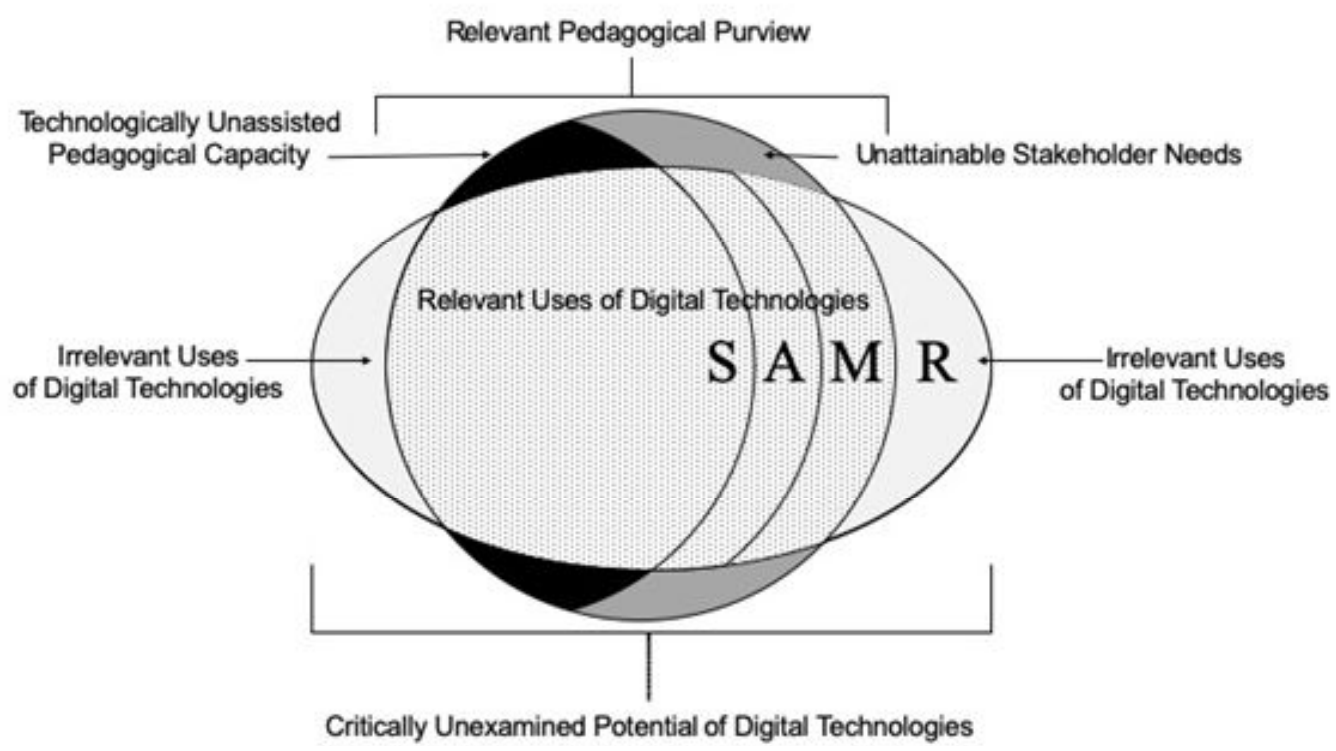




\section{Reflection Area \#1 (Implementation Motives): Why do I want to use technology?}

In an initial step toward refocus, our reflection begins with an honest assessment of our motives, which may include availability (i.e., We have it, so we might as well use it), novelty (i.e., Newer is better), edutainment (i.e., "Digital natives" enjoy using technology), pressure (i.e., The institution is requiring me to use it), and results (i.e., It improves learning outcomes).

An idealist might argue improvement of learning outcomes to be the only legitimate reason. However, with the exception of availability, essentially begging the question, any of the others might also be defensible, provided we do not lose sight of our ultimate pedagogical principles and purposes. For example, there is certainly no fault in using a more enjoyable learning activity so long as it yields equivalent pedagogical results.

In Freshman English, my main motive was institutional pressure. As I indicated earlier, I had no particular need for additional technology when mandatory tablet use was suddenly thrust upon me. In essence, I was looking to fit a purpose to a tool rather than reinvent my current teaching practices.

\section{Stage 3: Post-Initial Reflections}

The third stage of reflection deals with the areas of pedagogical purview and educational philosophy, the two of which might just as well be considered in the reverse order, depending on one's degree of professional autonomy. Whereas the educational philosophy of those acting primarily in an administrative capacity as curriculum or program director may inform their pedagogical purview, for those mainly in the instructional capacity of a classroom teacher, their philosophy is more likely to conform to it. As classroom teachers outnumber administrators, I have elected here to begin with pedagogical purview.

\section{Reflection Area $\# 2$ (Pedagogical Purview): Who are my stakeholders? What is my accountability to them? In what context?}

Our stakeholders include not only our students (and possibly their family members), with their given cultural backgrounds and language proficiency levels, but also our employers and colleagues, not to mention local communities and society at large. Their needs will depend on a number of contextual factors. In the case of learners, for example, they include scholastic level (i.e., primary, secondary, or tertiary) and course type (i.e., compulsory vs. elective) as well as the surrounding linguistic environment (i.e., one where the target language is routinely used in daily life vs. one where it is not). 
As society constantly evolves, so do the needs of its members, which could include anything from the traditional four communication skills, to content and language integrated learning in various academic subject areas, to C21 Canada's (2012) 21st Century Competencies (see Figure 8). Whatever the case, we must be clear on what our target learning outcomes are and whether technology use is essential or even useful to them.

Returning to Freshman English, it was a compulsory 15-week integrated skills course for first-year students at a private university in Japan, where students were streamed on the basis of paper-based Test of English as a Foreign Language (TOEFL) scores. My section of the course was in the highest tier, where the average score was 500. The class met for four 90-min lessons per week and focused on descriptive, narrative, expository, and persuasive rhetorical modes of communication. However, students were also expected to raise their TOEFL score to at least 550 by the end of the term.

\section{Reflection Area \#3 (Educational Philosophy): What do I see as the ultimate aim of language education?}

Four common educational philosophies are Idealism, Realism, Pragmatism, and Existentialism, each of which characterizes reality in a different way (see, for example, Tan, 2006). Its social and political implications aside, educational philosophy has an important influence on our concept of the very nature of language and, thus, our learners' eventual learning targets (see Figure 8 for example conceptualizations).

Our educational philosophy can, of course, change with time as a result of our environment and experiences. Whatever our present educational philosophy, however, the point is that we must ask ourselves how well different uses of technology reflect our worldview. In other words, how well does the language it exposes students to reflect the actual purposes for which they will need it?

Although, at heart, linguistically, I consider myself an Existentialist, in the case of Freshman English, pressure to raise students' standardized test scores by an average of 50 points necessitated an Idealist emphasis on standard, formal, academic language. By articulating my pedagogical purview and educational philosophy in this way, I was able to identify and eliminate irrelevant uses of digital technologies, which in my case included a redefinition of my current teaching practices (compare Figures 4 and 5). 


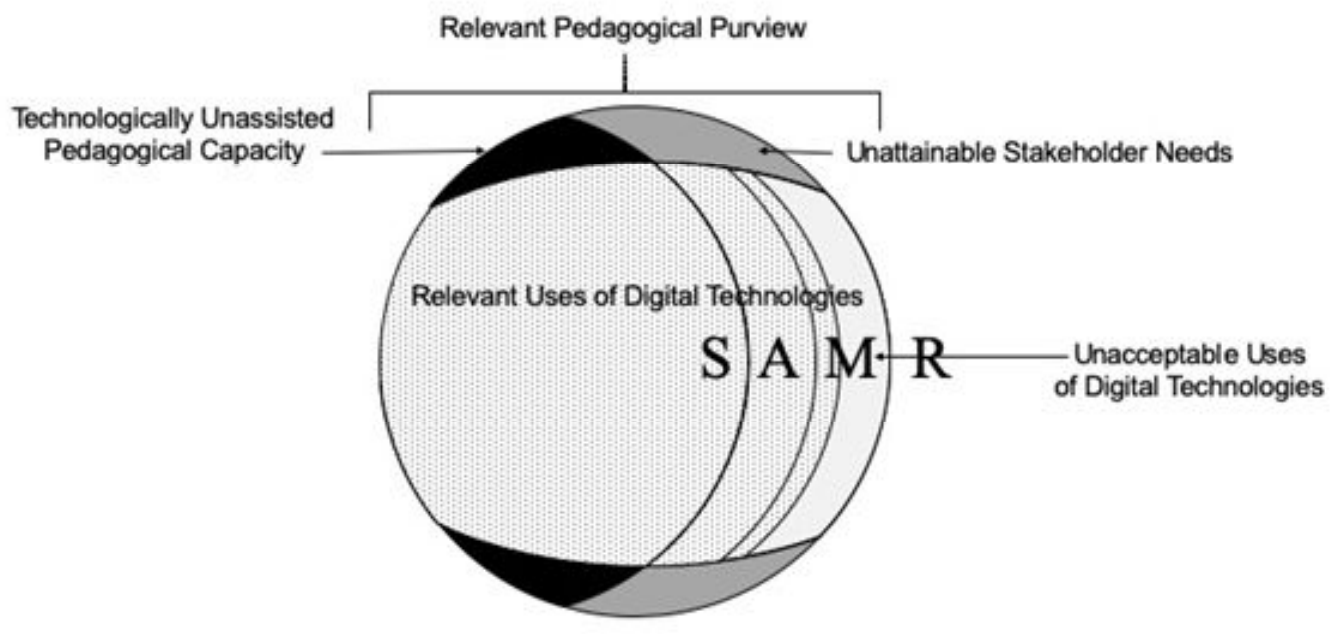

Figure 5. Post-initial reflection stage. SAMR = Substitution-Augmentation-Modification-Redefinition.

However, note that not all relevant uses of digital technologies necessarily resonate with us as teachers. Thus, the purpose of the penultimate reflection stage, encompassing the next two reflection areas, will be to eliminate the unacceptable.

Stage 4: Penultimate Reflections

\section{Reflection Area \#4 (Theory of Learning): How do I envision learning?}

Theories of learning generally fall into one of three broad categories-Behaviorist, Cognitive Constructivist, or Social Constructivist-each with its own definition of learning and conceptualization of the learning process (Berkeley Graduate Division Graduate Student Instructor Teaching and Resource Center, 2019; see Figure 8). Behaviorist theories, for instance, equate learning with the gradual chaining and shaping of reinforced responses to environmental stimuli. As such, they are often associated with repetitive drills accompanied by immediate positive and negative feedback. Cognitive Constructivist theories, in contrast, see learning as the integration of new information with existing mental structures (called schemata) through a process of assimilation or accommodation. Thus, the object is to create cognitive dissonance prompting learners to adjust their conceptual worldviews to explain incongruent evidence. Finally, Social Constructivist theories define learning as the assignment of meaning to new information vis-à-vis previous attitudes, beliefs, and experiences through a process of engagement in social interaction. Thus, unlike the previous views, both of which can minimally be realized by learners acting on impersonal elements of a self-contained environment, 
Social Constructivism necessitates the inclusion of actual autonomous human mediators.

As some theories explain some aspects of learning better than others, our views in this area, too, are subject to change. Moreover, until we arrive at a comprehensive theory, we can only focus on best explaining what is immediately within our grasp, but only once we have articulated our learning targets and the processes we believe most conducive to them can we begin to consider how well different technologies facilitate our envisioned learning process.

A program-level feature of the course design of Freshman English was the requirement that learners complete four small group projects (one on each rhetorical mode). Moreover, I believe that for post-adolescent learners in a foreign language environment such as my own to succeed, they need adequate motivation to attend to ample amounts of sufficiently salient comprehensible input. Thus, to these ends, I adopted a Social Constructivist perspective, targeting observation, analysis, and adaptation of expert products and performances.

\section{Reflection Area \#5 (Teaching Style): What kinds of interpersonal dynamics might best promote my target learning outcomes?}

Closely related to the idea of the learning process is the exact role of the learner in realizing it. Keegan (1993) identified four broad teaching styles or types of teacher-learner interaction, namely, Didactic (expert talks, novice listens), Socratic (expert asks, novice answers), Inquiry (novice asks, expert answers), and Discovery (novice talks, expert listens), each putting a progressively greater burden of investment on the learner. As Keegan himself points out, we cannot simply adopt the same dynamic in all our instruction, for the optimal choice depends on the motivation level of our learners and the need for instructional focus. In language teaching, for instance, we know that some linguistic features can be acquired implicitly, whereas others seem to require awareness raising and direct instruction. Thus, the question we must ask ourselves here is what role different technologies play in learner interactions.

The students in my Freshman English course, like many Japanese tertiary learners, finally relieved of having to study English solely for the purpose of university entrance exams, came characteristically enthusiastic about using English in class for daily conversation, notwithstanding that was not the main course objective. Thus, caught in a dialectic between students' desire for learner-centered lessons and my own strong conviction of the need for direct instruction, I opted for a largely Socratic approach, which would accommodate the learners' limited autonomy and their overreliance on teachers while still eliciting active engagement. By, thus, articulating my theory of learning and my basic teaching style, I was then able to identify and eliminate 
unacceptable uses of digital technologies, which in my case included most modification of my current teaching practices (see Figure 6).

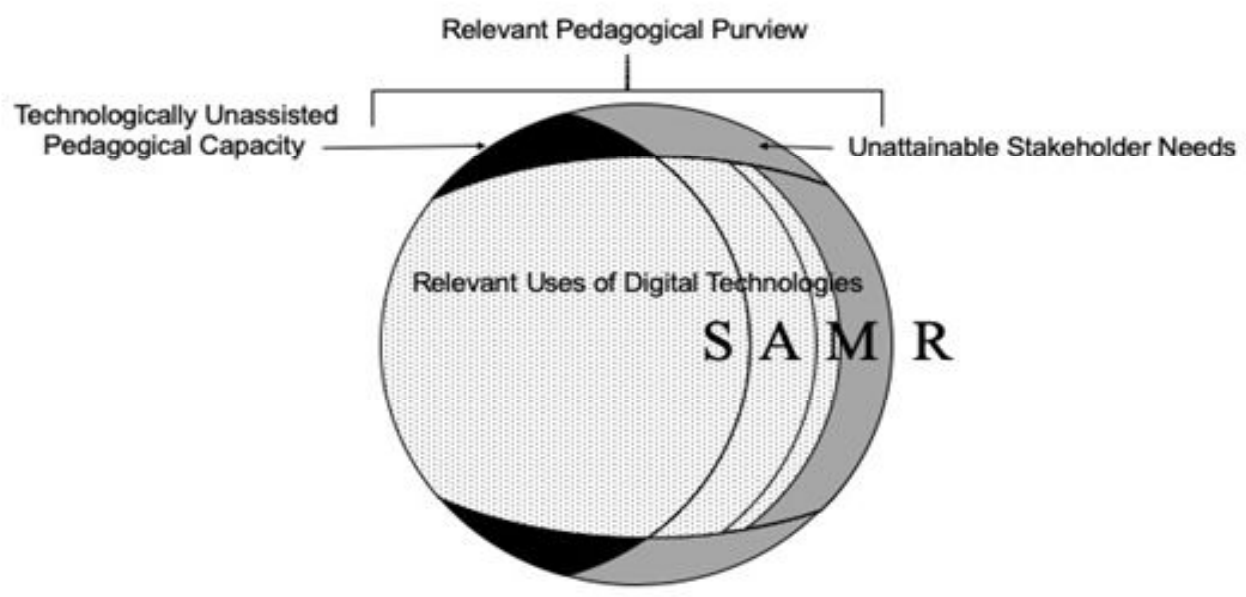

Figure 6. Penultimate reflection stage. SAMR = Substitution-Augmentation-Modification-Redefinition.

However, note that not all relevant and acceptable uses of digital technologies are necessarily feasible under other remaining situational constraints. Thus, the purpose of the final stage of reflection is to eliminate the situationally impossible.

Stage 5: Final Reflection

\section{Reflection Area \#6 (Situational Constraints): What other factors might limit my choices of technology use?}

Having carefully considered our motives, context, and beliefs, we can now suggest professionally responsible uses of educational technology. It only remains to ask what prevents us from using it the way we could or should. Among the most likely types of answer are personal, programmatic, logistical, and/or financial (see Figure 8). Personal constraints include technical skill deficiencies with regard to the hardware or software in question and ethical concerns about the sharing of private data. Programmatic constraints - the opposite of implementation pressures - would include the required use of a textbook. Logistical constraints involve inadequate facilities or equipment, such as lack of computer terminals or Wi-Fi access. Finally, financial constraints include lack of funding for technical support, upgrades, and new purchases.

At the time I taught Freshman English, frankly, I was anxious about my technical skills. Although tablets were new to all of us, every one of my stu- 
dents had a smartphone, and I did not, which suggested that they might master the devices more quickly and put me at an ever-increasing risk of losing face. Fortunately, my curriculum director was uncommitted to textbooks. Thus, I was given free rein with respect to my choice of teaching materials.

As the themes of the description and exposition units, I chose poetry and music, respectively. In both cases, I taught the students to use a slide presentation application to make multimodal presentations for their final projects.

For the narration and persuasion units, I chose the themes of fairy tales and environmental issues. Here, the final projects consisted of live performances, namely, a skit and a debate. Rather than graft technology onto these two what-I-considered sufficiently effective and engaging activities, I integrated it into my daily practice.

For the narration unit, the learners were studying genre conventions in order to dramatize and parody a famous fairy tale, for which I had them research and analyze models on YouTube. For the persuasion unit, I also had them conduct online research - in this case, on the pros and cons of their group's chosen topic. However, I then directed them to use collaboration software to create a slide show, which they would later individually present in jigsaw fashion to the members of the other groups in the lead-up to the formal debates.

Finally, for the purpose of studying for TOEFL, each week I had learner groups use the Academic Word List (Coxhead, 2000) to write multiple-choice test items, from which I drew randomly to create a short weekly online quiz.

Thus, as Figure 7 shows, my remaining situational constraints afforded digital technology substitution for some, but not all, of my current teaching practices. They also allowed me to expand my pedagogical capacity by augmenting and, to a lesser degree, modifying other practices.

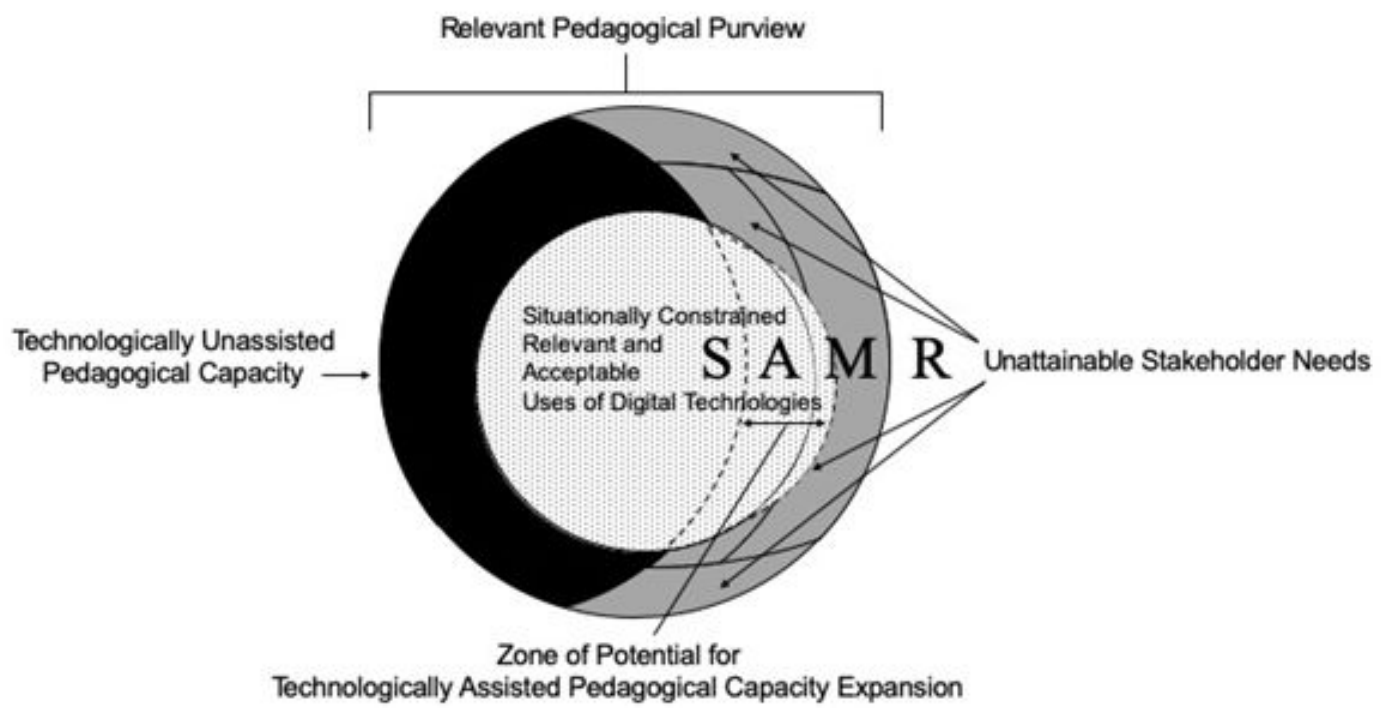

Figure 7. Final reflection stage. $S A M R=$ Substitution-Augmentation-ModificationRedefinition. 
Figure 8 recapitulates the entire five-stage reflection process, including the six key reflection areas, their driving questions, and possible answers.

\begin{tabular}{|c|c|c|c|}
\hline $\begin{array}{l}\text { Reflection } \\
\text { Stage }\end{array}$ & $\begin{array}{l}\text { Reflection } \\
\text { Area(s) }\end{array}$ & Driving Question(s) & Possible Answers \\
\hline $\begin{array}{l}\text { Pre-reflection } \\
\quad \text { (Fig. 3) }\end{array}$ & - & - & - \\
\hline $\begin{array}{l}\text { Initial } \\
\text { (Fig. 4) }\end{array}$ & $\begin{array}{l}\text { \#1: } \\
\text { Implementa- } \\
\text { tion Motives }\end{array}$ & $\begin{array}{l}\text { Why do I want to use } \\
\text { technology? }\end{array}$ & availability, novelty, edutainment, pressure, results \\
\hline \multirow[t]{2}{*}{$\begin{array}{l}\text { Post-initial } \\
\text { (Fig. 5) }\end{array}$} & $\begin{array}{l}\text { \#2: } \\
\text { Pedagogical } \\
\text { Purview }\end{array}$ & $\begin{array}{l}\text { Who are my } \\
\text { stakeholders? } \\
\text { What is my } \\
\text { accountability? } \\
\text { In what context? }\end{array}$ & $\begin{array}{l}\text { Stakeholders: employers, colleagues; learners (at } \\
\text { given maturity and proficiency levels) +/- family; } \\
\text { local communities, society at large } \\
\text { Context: second vs. foreign language } \\
\text { environment, primary vs. secondary vs. tertiary } \\
\text { institution, compulsory vs. elective course } \\
\text { Needs: traditional C-skills (listening, speaking, } \\
\text { reading, writing); credentialing (standardized test } \\
\text { results); content and language integrated learning } \\
\text { (CLIL); C21 Canada } 21 \text { st Century Competencies } \\
\text { (e.g., creativity, critical thinking, collaboration, } \\
\text { communication, character) }\end{array}$ \\
\hline & $\begin{array}{l}\text { \#3: } \\
\text { Educational } \\
\text { Philosophy }\end{array}$ & $\begin{array}{l}\text { What do I see as the } \\
\text { ultimate goal of language } \\
\text { education? }\end{array}$ & $\begin{array}{l}\text { Idealism: } \\
\text { native-like use of prescriptive language forms } \\
\text { Realism: } \\
\text { rule-based use of descriptive language forms } \\
\text { Pragmatism: } \\
\text { effective communication strategies } \\
\text { Existentialism: } \\
\text { linguistic awareness, reflective self-expression }\end{array}$ \\
\hline \multirow[t]{2}{*}{$\begin{array}{l}\text { Penultimate } \\
\text { (Fig. 6) }\end{array}$} & $\begin{array}{l}\text { \#4: } \\
\text { Theory of } \\
\text { Learning }\end{array}$ & $\begin{array}{l}\text { How do I envisage } \\
\quad \text { learning? }\end{array}$ & $\begin{array}{l}\text { Behaviorism: } \\
\text { positive reinforcement } \rightarrow \text { shaping and chaining } \\
\text { Cognitive Constructivism: } \\
\text { cognitive dissonance } \rightarrow \text { assimilation or } \\
\text { accommodation } \\
\text { Social Constructivism: } \\
\text { social interaction } \rightarrow \text { meaning making }\end{array}$ \\
\hline & $\begin{array}{c}\# 5: \\
\text { Teaching } \\
\text { Style }\end{array}$ & $\begin{array}{l}\text { What kinds of } \\
\text { interpersonal dynamics } \\
\text { might best promote my } \\
\text { target learning outcomes? }\end{array}$ & $\begin{array}{l}\text { Didactic: expert talks, novice listens } \\
\text { Socratic: expert asks, novice answers } \\
\text { Inquiry: novice asks, expert answers } \\
\text { Discovery: novice talks, expert listens }\end{array}$ \\
\hline $\begin{array}{l}\text { Final } \\
\text { (Fig. 7) }\end{array}$ & $\begin{array}{l}\text { \#6: } \\
\text { Situational } \\
\text { Constraints }\end{array}$ & $\begin{array}{l}\text { What other factors } \\
\text { might limit my choices of } \\
\text { technology use? }\end{array}$ & $\begin{array}{l}\text { Personal: technical skills, ethical concerns } \\
\text { Programmatic: required materials } \\
\text { Logistical: inadequate facilities or equipment } \\
\text { Financial: lack of funds }\end{array}$ \\
\hline
\end{tabular}

Figure 8. Summary of RADTILT stages, reflection areas, key questions, and possible answers. RADTILT = Reflective Approach to Digital Technology Implementation in Language Teaching. 


\section{Expanding Pedagogical Capacity}

Reviewing the resultant choices of the preceding reflection with regard to the SAMR model, you will find that they only occasionally surpassed the Enhancement level of Augmentation. As we have seen, however, before getting into the best use of technology, we need to be clear on exactly what we are tasked with teaching, to whom, and for what purpose, as well as how it is best taught and learned. In terms of the learner experience, I am not entirely convinced that using digital tools to make videos, for instance, would have been more "transformative" (in any sense of the word) or even more enjoyable than performing live skits, the end products of which could also have been uploaded and publicly shared if only I had recorded them. After all, technological affordances are not transformative in and of themselves, nor is transforming learning activities necessarily synonymous with transforming learners, for that matter. In fact, "transformation" is not even a desirable end if it entails sacrificing program goals or diminishing learning outcomes.

Despite its uncritical suggestion of the supremacy of transformation, judiciously used, the SAMR model can nevertheless still serve as a helpful stimulus to the discovery of previously unconsidered possibilities. For classroom teachers, this may result in expansion of their pedagogical capacity within their relevant purview. For program directors and curriculum planners, it may even prompt an expansion of the purview itself. In either case, the reflective approach presented here is intended as a crucial reminder of the contextually specific educational roles and goals that should inform all sound pedagogical decisions and, thus, lead to more responsive and responsible integration of digital technology in language teaching.

\section{Acknowledgement}

I would like to thank the two anonymous reviewers and the guest editor, Dr. Geoff Lawrence, whose many gracious comments and suggestions on the earlier drafts of this article improved its quality significantly.

\section{The Author}

Paul A. Lyddon, PhD (University of Arizona), is an associate professor in the Department of International Languages and Cultures at the University of Shizuoka, in Japan. His current research focuses on social semiotics, multimodality, and the use of information and communication technologies in digitally mediated intercultural communication.

\section{References}

Berkeley Graduate Division Graduate Student Instructor Teaching and Resource Center. (2019). Overview of learning theories. Retrieved from https:/gsi.berkeley.edu/gsi-guide-contents/ learning-theory-research/learning-overview/

Boyd, R. D., \& Myers, J. G. (1988). Transformative education. International Journal of Lifelong Education, 7, 261-284.

C21 Canada. (2012). Shifting minds: A 21st century vision of public education for Canada. Retrieved from www.c21canada.org/wp-content/uploads/2012/11/Shifting-Minds-Revised.pdf 
Coxhead, A. (2000). A new academic word list. TESOL Quarterly, 34, 235-253.

Crookes, G. (2016). Educational perspectives on ELT: Society and the individual; traditional, progressive and transformative. In G. Hall (Ed.), The Routledge handbook of English language teaching (pp. 64-76). New York: Routledge.

Hamilton, E. R., Rosenberg, J. M., \& Akcaoglu, M. (2016). The Substitution Augmentation Modification Redefinition (SAMR) model: A critical review and suggestions for its use. Tech Trends, 60, 433-441. https://doi.org/10.1007/s11528-016-0091-y.

Kash, W. (2018, March 9). Why technology is at a tipping point in U.S. schools. EdScoop. Retrieved from https://edscoop.com

Keegan, M. (1993). Optimizing the instructional moment: A guide to using Socratic, Didactic, Inquiry, and Discovery methods. Educational Technology, 33(4), 17-22.

Kukulska-Hulme, A., Lee, H., \& Norris, L. (2017). Mobile learning revolution: Implications for language pedagogy. In C. A. Chapelle \& S. Sauro (Eds.), The handbook of technology and second language teaching and learning (pp. 217-233). Hoboken, NJ: John Wiley \& Sons.

Mezirow, J. (1978). Perspective transformation. Adult Education Quarterly, 28(2), 100-110.

Puentedura, R. R. (2006, August 18). Transformation, technology, and education. Retrieved from http://hippasus.com/resources/tte/

Puentedura, R. R. (2015, October 14). SAMR: A brief introduction. [Blog post]. Retrieved from http://hippasus.com/rrpweblog/archives/2015/10/SAMR_ABriefIntro.pdf

Scherer, R., Siddiq, F., \& Tondeur, J. (2019). The technological acceptance model (TAM): A meta-analytic structural equation modeling approach to explaining teachers' adoption of technology in education. Computers \& Education, 128, 13-35.

Slavich, G. M., \& Zimbardo, P. G. (2012). Transformational teaching: Theoretical underpinnings, basic principles, and core methods. Educational Psychology Review, 24, 569-608.

Tan. C. (2006). Philosophical perspectives on education. In C. Tan, B. Wong, J. S. M. Chua, \& T. Kang (Eds.), Critical perspectives on education: An introduction (pp. 21-40). Singapore: Prentice Hall.

TESOL Technology Standards Project Team. (2008). TESOL technology standards framework. Alexandria, VA; TESOL. Retrieved from https://www.tesol.org/docs/default-source/books/ bk_technologystandards_framework_721.pdf 